\title{
POŠTA
}

TELEKOMUNIKÁCIE A

ELEKTRONICKY OBCHOD

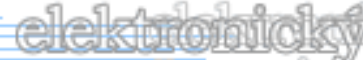

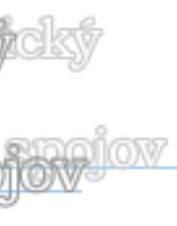

\section{EKONOMICKÉ DOPADY ZAVEDENIA DVB-T V SR}

\author{
Karol Hrudkay*
}

\begin{abstract}
Abstrakt
Článok sa zaoberá ekonomickými dopadmi zavedenia pozemského digitálneho televízneho vysielania v SR a to jednak na domácnosti ale aj na podnikatel'skú sféru a verejné financie. Podstatná čast' je venovaná práve dopadom na domácnosti, ktoré v konečnom dôsledku rozhodnú o úspechu prechodu na digitálnu televíziu, a to z pohl'adu možnosti príjmu televízneho signálu.
\end{abstract}

\section{Úvod}

Tlak na efektívnejšie využívanie frekvenčných pásiem vyhradených pre televíziu vytvárajú nové služby a technológie podporujúce mobilitu. Je preto nevyhnutná revízia medzinárodných koordinačných dohôd na európskej i svetovej úrovni, ktorá sa dotkne aj SR.

Proces prechodu na digitálne vysielanie si vyžaduje legislatívu, ktorá ho bude podporovat' a nespôsobovat' jeho zdržanie. Konkretizovat' však ekonomické dopady je možné len v súvislosti s uceleným návrhom na legislatívne zmeny na základe jasnej legislatívnej stratégie. Základným predpokladom pre úspešný prechod od analógového na digitálne vysielanie je záujem vysielatel'ov, poskytovatel'ov/prevádzkovatel'ov vysielacích sietí a samozrejme obyvatel'stva SR. Na priame financovanie pilotného projektu digitálneho vysielania neboli zo štátneho rozpočtu vyčlenené žiadne finančné prostriedky. Skúšobné vysielanie bolo financované priamo prevádzkovatel'mi, ktorí boli vybraní vo výberovom konaní. Obdobnú situáciu je možné očakávat’ aj pri prechode od analógového vysielania na riadne digitálne vysielanie t.j. bez akejkol'vek priamej štátnej pomoci.

V procese prechodu od analógového na digitálne vysielanie možno očakávat' rôzne ekonomické dopady. Ide najmä o dopady na obyvatel'stvo a podnikatel'skú sféru a neposlednom rade aj na verejné financie.

Digitalizácia televízneho (i rozhlasového) vysielania znamená predovšetkým rozšírenie liberalizácie mediálneho trhu, možnost' zvýšenia počtu vysielaných programov, ked’že v porovnaní s analógovým vysielaním digitálne systémy dovol'ujú v danom pásme umiestnit' väčší počet programov a $\mathrm{k}$ tomu ešte niekol'ko d'alších telekomunikačných služieb. Na základe uvol'nenia frekvenčného spektra dôjde k možnosti jeho d’alšieho využitia. Dochádza tak k zefektívneniu využitia frekvenčného spektra.

Vo frekvenčnom spektre je pri zavádzaní digitálneho vysielania nutné robit' vel'mi rozsiahle presuny, čo si vyžaduje rozsiahlu medzinárodnú koordináciu. V dôsledku týchto zmien dochádza $\mathrm{k}$ postupnému obmedzovaniu funkcie analógových systémov, a tým i v niektorých lokalitách ku zhoršeniu príjmu existujúceho analógového vysielania.

\footnotetext{
* Ing. Karol Hrudkay

Výskumný ústav dopravný, a.s., Vel'ký Diel 3323, 01008 Žilina,

tel.: ++421/41/5686 337, e-mail: hrudkay@vud.sk
} 
Komunikácia $\mathrm{s}$ účastníkmi na trhu služieb audiovizuálneho obsahu a jeho prenosu $\mathrm{k}$ spotrebitel'om je nedostatočná. Odhliadnuc od výročných správ regulátorov služieb obsahu a prenosu (Rada pre vysielanie a retransmisiu a Telekomunikačný úrad SR) nie sú verejnosti bežne dostupné aktuálne údaje o štruktúre vysielania (terestriál, kábel, satelit), ich pokrytia územia a obyvatel'stva. Obdobne sa to týka údajov o výsledkoch činnosti Skupiny pre digitálne vysielanie (SKDV), či priebežných výsledkov pilotného digitálneho vysielania. Informovanost' spotrebitel'ov o prechode $\mathrm{z}$ analógového na digitálne vysielanie a jeho dôsledkoch je mizivá a zatial' neboli verejne dostupné ani výsledky žiadneho prieskumu, ktoré by na povedomie obyvatel'stva o tejto záležitosti poukazovali. Záujem o digitálne vysielanie je evidentný len u poskytovatel'ov služieb prenosu, ktorí sa aktívne zapojili do procesu pilotných projektov DVB-T na Slovensku. Získaním frekvencií pre digitálny multiplex by mali mat' zaručený odbyt pri poskytovaní svojich sietí.

Ukončenie analógového vysielania Slovensko deklarovalo EK v roku 2012, avšak v súčasnosti neexistuje žiaden záväzný termín pre začatie pravidelného digitálneho vysielania. Znamená to, že pôvodný plán začatia pravidelného vysielania v roku 2005 podl'a materiálu „Národná politika pre elektronické komunikácie“, schváleného uznesením vlády SR č. 196 z r. 2003, nebol dodržaný. V tejto súvislosti je potrebné aktualizovat' materiál „Stratégia a technické kritériá na zavedenie pozemského digitálneho TV vysielania v systéme DVB-T na Slovensku“, ktorý bol schválený uznesením vlády SR č. 589 z 27. júna 2001 a na ktorého ciele sa Národná politika odvoláva (uznesením vlády SR č. 5/2006 bolo ministrovi MDPT SR uložené do 30.6.2006 predložit' návrh stratégie prechodu na digitálne pozemské TV vysielanie a predsedovi Telekomunikačného úradu SR (TÚ SR) bolo odporučené vyhlásit' výberové konanie na poskytovatel'ov sietí pre digitálne vysielanie v systéme DVB-T do 30.6.2007). Faktom zostáva, že jedným $\mathrm{z}$ najväčších problémov je zdĺhavý proces medzinárodnej koordinácie frekvencií pre digitálne vysielanie.

\section{Dopady zavedenia DVB-T na obyvatel'stvo}

Dopady zavedenia digitálnej pozemskej televízie a vypnutia analógového vysielania pozemskej televízie je potrebné starostlivo vyhodnotit' tak, aby bolo zrejmé, či si podstatná čast' domácností môže s tým súvisiace zariadenie dovolit' zakúpit'.

Najväčšia čast' obyvatel'stva, ktorej sa to bytostne dotýka, je tá, ktorá prijíma televízny signál v súčasnosti prostredníctvom svojej individuálnej antény (určenej na príjem signálu v televíznych pásmach TV I, III a IV). V menšej miere sa to týka ostatných domácností, hlavne tých, ktoré využivajú signál z káblových sietí, príp. spoločných televíznych antén STA (pre túto skupinu domácností je potrebné prehodnotit', či je vhodné investovat' do ich obnovy pozri d'alej).

Je zrejme možné očakávat', že je nezanedbatel'ný počet domácností, ktoré vlastnia a aj používajú viacero televíznych prijímačov. V súčasnosti sa takýto štatistický údaj v SR nesleduje, podiel takýchto domácností (i s údajom o počte TV prijímačov v domácnosti) bol zist'ovaný v rámci realizovaného celoslovenského prieskumu (pozri tab. 1). Vidiet' teda, že viac ako jeden prijímač má takmer $38 \%$ domácností, priemer je takmer 1,5 TV prijímača na domácnost'. Aj v tomto prípade bude záležat' na finančných možnostiach a spôsobe príjmu televízneho signálu v týchto domácnostiach, ako sa vysporiadajú s prechodom na digitálne pozemské vysielanie. 
Tabul'ka 1 Počet TV prijímačov v domácnostiach podl'a celoslovenského prieskumu

\begin{tabular}{|c|c|}
\hline Počet funkčných TV prijímačov v domácnosti & Relatívne zastúpenie domácností [\%] \\
\hline 0 & 1,0 \\
\hline 1 & 61,3 \\
\hline 2 & 32,1 \\
\hline 3 a viac & 5,6 \\
\hline
\end{tabular}

Následovný rozbor vychádza z dostupných štatistických údajov a odhadov, nakol'ko niektoré potrebné údaje pre stanovenie požadovaných výsledkov neboli k dispozícii.

Posledné sčítanie sa realizovalo v roku 2001 (SODB 2001), kedy sa zistilo, že na Slovensku je:

- 1884846 bytov, v ktorých žije 5298937 osôb a že

- farebný televízny prijímač má 1410358 bytov, v ktorých žije 4658366 (čo predstavuje $74,83 \%$ bytov a $87,91 \%$ osôb) ${ }^{1}$.

Ked’že od dátumu uskutočnenia tohto sčítania (máj 2001) ubehlo 5 rokov, bolo potrebné upravit' tento údaj o prírastok bytov za obdobie od konania SODB do súčasnosti. Ku koncu roku 2005 teda v SR približne o 52894 bytov viac, teda celkovo asi 1937740 bytov.

Aktuálnejšie avšak odlišné údaje poskytuje novšie štatistické zist'ovanie Štatistického úradu ŠÚ SR (Zist'ovanie o informačných a komunikačných technológiách v domácnostiach) realizovaného v januári 2005. Podl'a tohoto zist'ovania je

- 90,2\% domácností vybavených televíznym prijímačom a z toho má

- $27,1 \%$ satelitný prijímač a

- 45,1\% má signál z kábelovej siete.

Dá sa predpokladat', že domácnosti vybavené satelitným prijímačom majú aj iný zdroj televízneho signálu, nakol'ko je relatívne malý počet požívatel'ov satelitnej služby, ktorá poskytuje aj signál tuzemských televíznych staníc (názov tejto služby je Slovak Link).

Podl'a posledných známych údajov TÚ SR bolo k 31.12.2003 v SR:

- 550 káblových distribučných sietí (KDS) so

- 720840 účastníckymi zásuvkami

- t.j. priemerná KDS mala 1310 zásuviek.

Novšie údaje TÚ SR neposkytuje, lebo ich už ani nevyžaduje (podl'a všeobecných povolení majú prevádzkovatelia KDS voči TÚ iba oznamovaciu povinnost').

Údaje o držitel'och registrácie retransmisie poskytuje aj Rada pre vysielanie a retransmisiu (RVR), ktoré sú k 25.5.2006 uvedené v tabul'ke č. 2.

Z uvedenej tabul'ky vyplýva, že dominantným hráčom na trhu KDS je UPC Slovensko, s.r.o. s celkovým počtom prípojok 336766 , čo predstavuje podiel na trhu približne $42 \%$ (KDS prevádzkuje v 28 obciach a MMDS v 4, čo znamená že prevádzkuje relatívne vel'ké kábelové siete).

\footnotetext{
${ }^{1} \mathrm{Na}$ základe týchto údajov je možné predpokladat', že počet prijímačov a teda aj počet domácností vybavených TV prijímačom je značne vyšší. Súvisí to zrejme s tým, že pri sčítaní občania neradi vykazujú údaje o svojom „luxuse“, naopak údaj z tab. č. 1 o počte domácností bez TV prijímača sa môže realite viac približovat', resp. môže byt' v skutočnosti aj mierne vyšší (vyplýva to zo spôsobu realizácie prieskumu, kedy anketári navštevovali respondentov $\mathrm{v}$ domácnosti).
} 
Tabul'ka 2 Údaje o držitel'och registrácie retransmisie podl'a spôsobu širenia

\begin{tabular}{|c|c|c|l|}
\hline Typ siete & Počet prípojok & Počet držitel'ov & Poznámky \\
\hline KDS & 715710 & 131 & Z toho UPC $316766(44,26 \%$ podiel $)$ \\
\hline MMDS & 86964 & 13 & Z toho UPC $20000(23 \%$ podiel $)$ \\
\hline MVDS & 262 & 2 & \\
\hline Spolu & 802936 & 145 & Z toho UPC $336766(41,94 \%$ podiel $)$ \\
\hline
\end{tabular}

Z nasledovného grafu (podl'a údajov RVR) je vidiet', že trh v oblasti KDS je ustálený a je badat' mierny medziročný nárast.

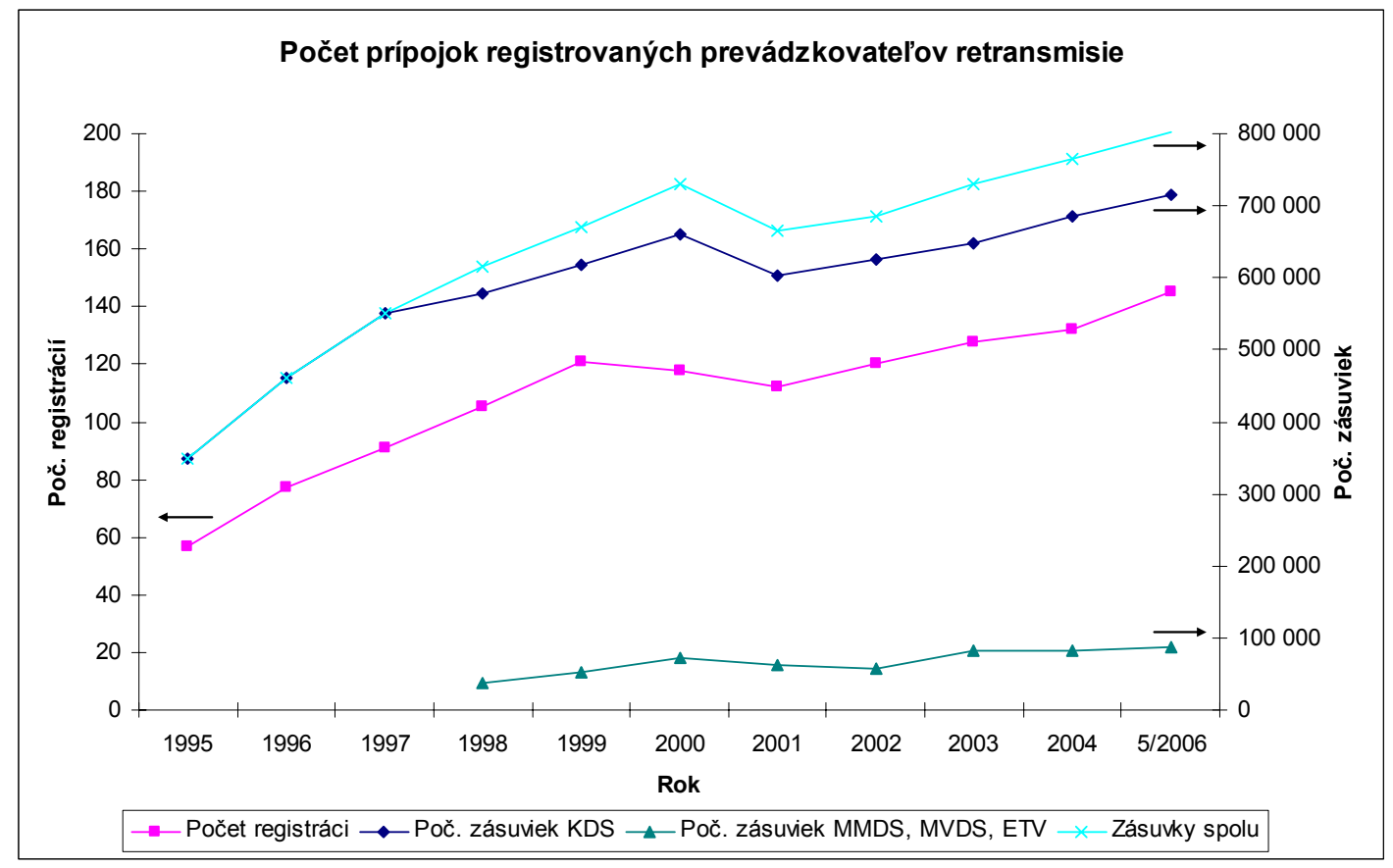

Graf 1 Počet prípojok držitel’ov registrácie retransmisie

Ako už bolo vyššie uvedené, dá sa predpokladat', že prechod na pozemskú digitálnu televíziu by sa v menšej miere dotkol abonentov služby Slovak Link, v rámci ktorej sa vysiela 13 rozhlasových programov a 5 TV programov - Markíza, STV 1, STV 2, JOJ a TA3 (prechod na DVB-T by sa týkal použivatel'ov, ktorí by požadovali aj iné služby DVB-T alebo ponuka programov Sloval Link by sa nerozšírila a ponuka pozemského vysielania by bolo bohatšia).

Čo sa týka počtu sietí STA (spoločné televízne antény), údaje o nich sa nevedú, TÚ SR sa o tieto prípady zaujíma iba v prípade st'ažností (napr. rušenia, nedovoleného vyžarovania a pod.), RVR táto oblast' registrácie nepodlieha. V materiále Stratégia a technické kritériá na zavedenie pozemského digitálneho TV vysielania v systéme DVB-T na Slovensku z roku 2001 bol uvedený odhad, že:

- v približne 16000 siet’ach STA je

- pripojených približne 370000 účastníkov,

- čiže priemerná STA má 23 účastníkov (najväčšie siete STA majú 100 účastníkov).

V prípade prechodu na DVB-T bude treba tieto STA patrične obnovit', t.j. nahradit' príslušné zariadenia, ktoré slúžili na analógový príjem (zosilňovače, meniče) za zariadenia potrebné pre príjem $\mathrm{v}$ systéme DVB-T. Ak budeme uvažovat' iba 2 multiplexy t.j. 8 programov (predpokladajú sa 4 programy na 1 multiplex), v hlavnej stanici STA bude 
potrebných taktiež 8 prijímačov DVB-T. Ked’že cena takýchto prijímačov je vyššia ako cena bežných prijímačov (STB) určených na individuálny príjem (pretože obyčajne musia spíňat' vyššie požiadavky na technické parametre, sú spol’ahlivejšie a musia splńnat vyššie požiadavky na odolnost' proti klimatickým vplyvom), treba prebudovanie STA zvážit' od prípadu $\mathrm{k}$ prípadu, a to predovšetkým podl'a vel'kosti siete (počtu účastníkov, príp. počtu d’alších programov resp. iných služieb) a podl'a očakávaní účastníkov (zrejme ak bude hlavná stanica STA slúžit’ iba ako „konvertor“ signálu DVB-T na signál analógovej televízie, t.j. PAL signál, účastníci nebudú mat' prístup $\mathrm{k}$ d’alším službám, resp. benefitom, ktoré môže digitálna televízia poskytnút', napr. interaktivitu, internet).

Druhou jednoduchšou alternatívou je, že STA bude už slúžit' iba ako distribučná siet' pre vysokofrekvenčný televízny signál s využitím zosilňovača alebo len frekvenčného meniča (je t'ažké si predstavit', že každý byt vo väčšom bytovom dome by mal vlastnú anténu pre individuálny príjem) a každá domácnost' by mala svoj vlastný STB (samozrejme v prípade, že pokrytie signálom DVB-T nebude natol'ko kvalitné, že bude možný príjem na malú „izbovú“ anténu). $\mathrm{V}$ tomto prípade by mali domácnosti dostupné všetky poskytované vymoženosti digitálnej televízie, a to v závislosti od možností ich STB.

Pre jednoduchost' uvažujme, že:

- najlacnejšie STB dostupné na trhu určené pre štandardné použitie budú za $3000 \mathrm{Sk}$,

- prijímače pre domovú stanicu približne za 15000 Sk (predpokladá sa, že táto suma je aj s montážou).

Nasledujúci graf na takomto jednoduchom príklade ozrejmuje efektivitu investícií do obnovy siete STA (bytovým riešením sa označuje prípad, kedy má každá domácnost' svoj STB - predpokladajú sa rovnako drahé STB; domovým riešením sa označuje použitie STB hlavnej stanici STA). Je vidiet', že táto efektivita závisí jednak:

- od vel'kosti STA (počtu zásuviek),

- od počtu prijímaných programov (multiplexov),

- od ceny ,izbového“ STB (určuje strmost') a

- od ceny „spoločného“ STB (určuje posuv smerom hore-dole). 


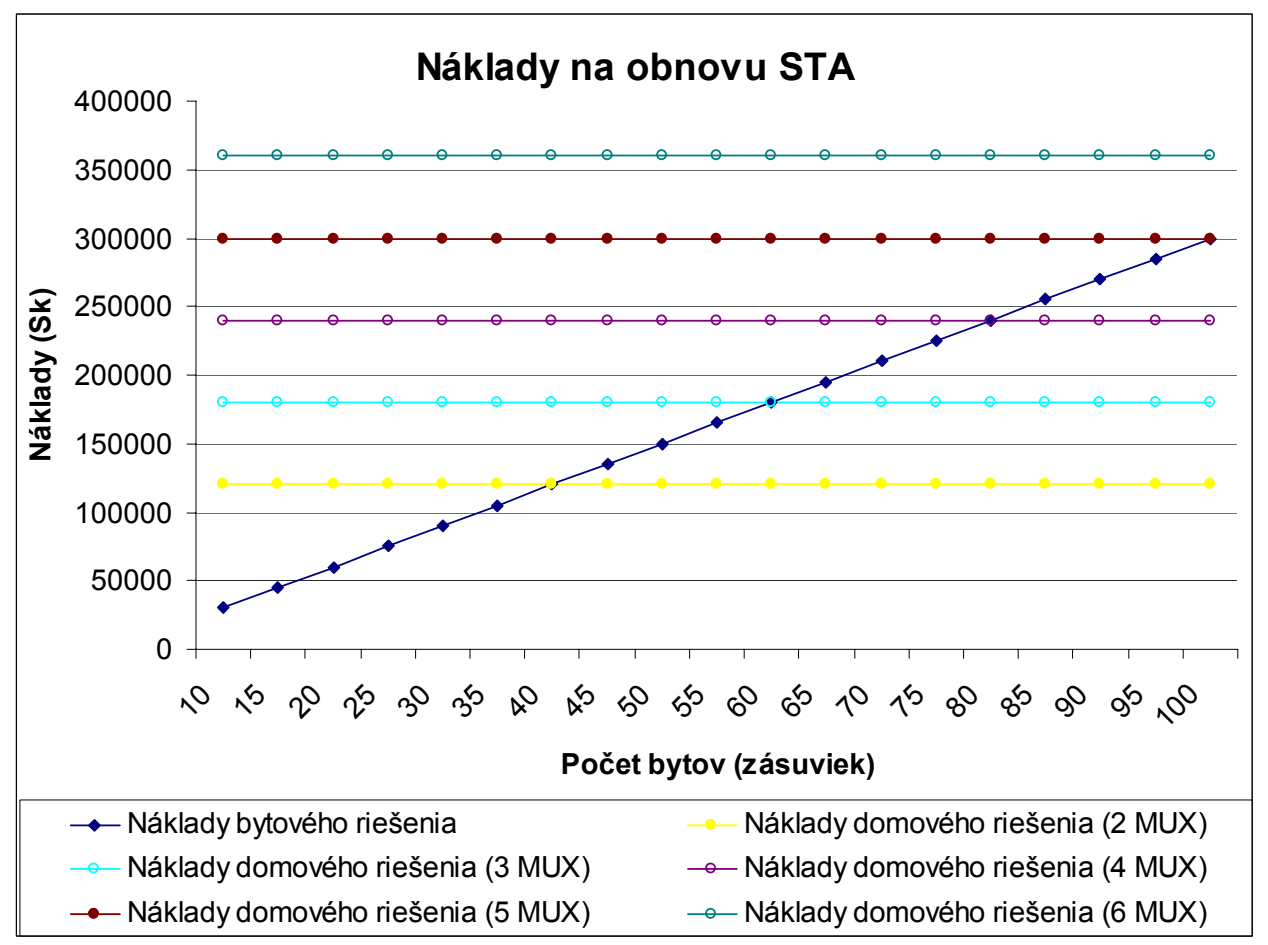

Graf 2 Náklady spojené s obnovou STA sietí pri prechode na DVB-T

Pre úplnost' treba poznamenat', že domácností s príjmom TV signálu prostredníctvom KDS (spolu s mikrovlnovými distribučnými systémami, ako sú MMDS, MVDS) sa prechod na digitálne vysielanie dotkne najmenej. Dá sa predpokladat', že drvivá väčšina účastníkov KDS bude mat' po zavedení DVB-T aspoň takú ponuku TV programov ako dnes, samotný prechod na DVB-T sa ich finančne nedotkne (prípadné investície operátora KDS do jej obnovy alebo vylepšenia účastníci KDS zaplatia nepriamo prostredníctvom platieb za služby).

Celkové náklady domácností v SR súvisiacich s prechodom na DVB-T sa skladajú z:

- nákladov na dovybavenie domácností prijímačom (STB) - bude sa to týkat' najmenej 690 tis. domácností (pozri tab. 3),

- nákladov na obnovu hlavných staníc STA väčšinou z tzv. fondu opráv bytových domov - týka sa to približne 16000 sietí STA, čo zahŕňa približne 400 tis. domácností (samozrejme, podl'a vyššie uvedeného zjednodušeného rozboru čast' STA sa neoplatí obnovovat' a tieto STA sa prestanú používat' a príslušné domácnosti sa presunú do predošlej „kategórie“ alebo sa pripoja na KDS).

Tabul'ka 3 Odhad počtu domácností s individuálnym prijmom TV signálu

\begin{tabular}{|l|l|l|}
\hline Typ domácnosti & Počet [tis.] & Poznámka \\
\hline $\begin{array}{l}\text { Celkový počet domácností } \\
\text { (bytov) v SR }\end{array}$ & 1937 & $\begin{array}{l}\text { Pre jednoduchost' a rozdiely vo vybavenosti TV prijímačmi sa } \\
\text { uvažovalo so všetkými domácnostami } 2\end{array}$ \\
\hline Počet domácností s KDS & 803 & Zdroj: RVR \\
\hline Počet účastníkov Slovak Link & 45 & Odhad \\
\hline Počet domácností S STA & 400 & Odhad z r. 2001 + polovica nových bytov od r. 2001 do r. 2005 \\
\hline $\begin{array}{l}\text { Počet domácností } \\
\text { s individuálnym prijmom }\end{array}$ & 689 & V prípade, že všetky STA budú obnovené pre prijem DVB-T \\
\hline
\end{tabular}

${ }^{2}$ t.j. podl’a SODB 2001 bolo vybavených farebným TV prijímačom 74,8\% bytov, podla zist'ovania ŠÚ SR o IKT (1/2005) bolo $90,2 \%$ domácností vybavených TV prijímačom a podl'a celoštátneho prieskumu (12/2005) nemá TV prijímač iba $1 \%$ domácností 
Na tomto mieste treba ešte zdôraznit', že zavedenie DVB-T môže priniest' pre domácnosti $\mathrm{s}$ individuálnym príjmom d’alšie pozitívum, a to tým, že štát stanoví pre prevádzkovatel’ov vysielacích sietí také licenčné podmienky, ktoré umožnia týmto účastníkom príjem na jednu anténu (vysielanie z pohladu prijímatel'a signálu DVB-T bude uskutočňované z jedného vysielacieho miesta). Toto jednoduché opatrenie výrazne napomôže presadzovaniu sa DVB-T medzi obyvatel'stvom, ale môže mat' dokonca aj vplyv na výšku nákladov na vybudovanie vysielacej siete .

Z hladiska ekonomických dopadov na spotrebitel'a/domácnosti je teda možné konštatovat', že digitálne vysielanie si bude vyžadovat' od značného podielu domácností (cca 1,1 mil.) náklady na obstaranie si bud' digitálnych televíznych prijímačov alebo STB resp. investície do obnovy STA, no z celoslovenského hl'adiska by to nemalo mat' však žiadny vážny sociálny dopad alebo vplyv na dostupnost' vysielania verejnej služby. Problematickými sa môžu stat' iba nízkopríjmové domácnosti v ekonomicky slabých regiónoch a na vidieku (prieskum poukázal na to, že práve táto skupina má o digitálnu televíziu najväčší záujem a že medzi domácnost'ami, ktoré sú ochotné investovat' do STB, je ochota investovat' viac ako 3000 Sk ojedinelá).

\section{Dopady zavedenia DVB-T na podnikatel'skú sféru}

Vypnutie analógového televízneho vysielania a začatie vysielania podla štandardu DVB-T prinesie v obmedzenej miere pre podnikatel'skú sféru jednak negatíva, a to tým, že sa budú musiet' situácii prispôsobit' po technickej stránke, ale aj pozitíva.

Pozitíva budú spočívat' $\mathrm{v}$ tom, že $\mathrm{v}$ rámci vol'ného trhu prinesie slovenským podnikatel'ským subjektom možnost' zapojit' sa do výroby potrebných zariadení pre výstavbu sietí pre šírenie signálu pozemskými vysielačmi i pri prestavbe kábelových sietí a STA, ktoré distribuujú takto šírený signál $\mathrm{k}$ spotrebitel'om. Po vypnutí analógových vysielačov bude prechod značným prínosom aj pre vysielatel’ov (v súčasnosti podl'a údajov MK SR šíri signál svojej televíznej programovej služby prostredníctvom pozemského televízneho vysielania 15 subjektov, pričom všetky subjekty šíria signál aj prostredníctvom KDS), pretože im môžu reálne klesnút' náklady za šírenie signálu $\mathrm{v}$ prepočte na 1 program (podl'a skúseností zo zahraničia sa predpokladá pokles na úroveň približne $50 \%$ zo súčasných nákladov).

Konkrétne sa výhody digitálnej televízie prejavia aj u výrobcov televíznych prijímačov a set-top boxov, ktorí budú nútení prichádzat' na trh stále s niečím novým, čo by oslovolo spotrebitel'ov. Taktiež je možné očakávat' zisky napríklad pri poskytovaní nových interaktívnych služieb, ktoré budú súčastou súhrnného dátového toku digitálneho vysielania.

Negatíva spočívajú v nákladoch príslušných subjektov najmä v súvislosti s výstavbou nových technológií. Je totiž nutné vybudovat' siete pozemského digitálneho vysielania vo frekvenčnom pásme, kde v súčasnosti pracujú analógové vysielače, t.j. pôjde o spracovanie projektov sietí, projektov rekonštrukcií a výstavby, obmenu vysielačov, prípadne postavenie nových stredísk a stanovíśt' atd'. ${ }^{3}$.

Negatívny dopad pre vysielatel'a predstavujú dodatočné náklady na paralelné šírenie signálu dvoma spôsobmi (analógovo a digitálne) počas doby trvania prechodného obdobia (aj to je jeden z dôvodov, prečo je vhodné dobu prechodu skrátit'). Mnohí vysielatelia plánujú rozšírenie svojej programovej ponuky, čo si vyžaduje taktiež nemalé investície.

\footnotetext{
${ }^{3}$ Túto výšku je nemožné stanovit’ bez príslušnej legislatívy a bez znalosti obchodných plánov prevádzkovatel'ov týchto vysielacích sietí (kvalifikované odhady hovoria o $1 \mathrm{mld}$. Sk pre vybudovanie jednej siete, pre vybudovanie d'alších sietí bude treba cca $0,8 \mathrm{mld}$. Sk/siet', pričom úspora sa dá dosiahnut' hlavne „zdiel'aním“ jednak stavebných objektov a tiež komunikačných liniek).
} 
Prechod na DVB-T sa, v obdobnej miere ako u obyvatel'stva, dotkne aj podnikatel'ských subjektov - fyzických osôb - podnikatel'ov a právnických osôb. Podl'a údajov STV, v tejto kategórii koncesionárov je evidovaných 13620 osôb, ktoré mali prihlásených $46484 \mathrm{TV}$ prijímačov. Tieto si budú vyžadovat' obdobné investície, ako to bolo rozoberané v predchádzajúcej časti pre obyvatel'stvo.

\section{Dopady zavedenia DVB-T na verejné financie}

V oblasti verejných financií proces digitalizácie vysielania nevyvolá nárast pracovných síl vo verejnej a štátnej správe. Nároky na štátny rozpočet alebo iné verejné rozpočty súvisia $\mathrm{s}$ tým, pre akú podporu rozvoja DVB-T sa vláda, resp. príslušné ministerstvá rozhodnú, pričom budú rešpektované odporúčania EK. Ako však Komisia v stanovisku č. IP/05/1394 z 9.11.2005 konštatuje, ,prechod na digitálne vysielanie sa môže oneskorit', ak sa tento prechod nechá úplne na trhové mechanizmy; užitočné sú zásahy verejného sektora formou regulácie, finančnej podpory spotrebitel'ov, informačnej kampane alebo dotáciami na prekonanie určitých zlyhaní trhu alebo na zistenie sociálnej alebo regionálnej súdržnosti“". Podpora rozvoju DVB-T zo strany štátu je možná len v rámci pravidiel EÚ pre hospodársku sút’až. Tieto pravidlá čiastočne upresnila EK, ako istú pomôcku, vo svojom vyjadrení k prípadu štátnej pomoci pre DVB-T v Nemecku.

EK odporúča v prípade poskytovania štátnej pomoci pre DVB-T zamerat' sa napr. na podporu rozvoja prenosových sietí v oblastiach, kde je nedostatočné pokrytie TV signálom, poskytnutie náhrady vysielatel'om, ktorí sú povinní ukončit' analógové vysielanie skôr ako im skončí platnost' príslušnej licencie alebo podporit' spotrebitel'ov pri zaobstarávaní digitálnych dekóderov (aby nízkopríjmové domácnosti nestratili prístup k televízii). Taktiež schvaluje podporu pilotných projektov a podporu výskumu. Možné sú aj granty spoločnostiam na vývoj inovatívnych digitálnych služieb a dotácie vysielatel'om na kompenzovanie zvýšených nákladov počas paralelnej prevádzky analógového a digitálneho vysielania.

Politická únosnost' podpory spočíva vo vytvorení takých podmienok pre rozvoj DVBT, ktoré nepripustia zaostávanie SR za inými štátmi EÚ, trvalo nenarušia hospodársku sút'až a nebudú v rozpore so spomínanými pravidlami. Podstatné dva legislatívne kroky na podporu DVB-T boli už $\mathrm{v}$ Slovenskej republike uskutočnené schválením novely zákona o elektronických komunikáciách v NR SR dňa 13. 12. 2005. Žial', tento zákon bol prezidentom SR do parlamentu vrátený.

Prvým významným legislatívnym krokom je skutočnost', že používanie frekvencií určených na digitálne vysielanie by bolo počas prechodného obdobia do roku 2012 oslobodené od platenia úhrad. Predstavuje to protihodnotu za efektívnejšie využívanie frekvenčného spektra. Presná hodnota nie je známa, pretože mechanizmus platenia úhrad za používanie frekvencií na digitálne vysielanie nie je ešte špecifikovaný. Rádovo však pôjde o desiatky miliónov korún, ktoré môžu vysielatelia použit' pri budovaní sietí. Druhým legislatívnym krokom by bolo schválenie novely zákona o správnych poplatkoch (v rámci novely zákona o elektronických komunikáciách), kde by došlo $\mathrm{k}$ zníženiu poplatkov $\mathrm{v}$ položke 13, a tieto predstavujú významné zníženie nákladov pre vysielatel'ov, čo je možné považovat' za podporu tvorby obsahu.

Na základe uvedeného je možné konštatovat', že v blízkej budúcnosti bude nevyhnutné viac ako doteraz zapojit' prostriedky štátu do procesu priamej podpory DVB-T. Je vhodné túto podporu rovnomerne rozdelit' tak, aby podporila dosiahnutie záujmov štátu, spotrebitel'ov, vysielatel'ov a prevádzkovatel'ov vysielacích sietí pri prechode na digitálne vysielanie. Zostáva zabezpečit' primerané motivovanie záujmu spotrebitel’ov a vysielatel'ov. 
Vyššie spomenuté nepriame nástroje podpory je vhodné doplnit' priamou intervenciu štátu. Pre spotrebitel'ov je jedno z riešení podpora pri kúpe set-top-boxov všetkým koncesionárskym domácnostiam. Zodpovedalo by to všeobecnému očakávaniu, že oni by mali byt' hlavní propagátori DVB-T. V prospech toho hovorí súčasný systém vyberania a použitia koncesionárskych poplatkov. Pre štát je vhodné podporovat' budovanie siete $\mathrm{v}$ oblastiach, kde je v súčasnosti obmedzený alebo žiadny príjem pozemského vysielania na báze podpory investícií $\mathrm{v}$ niektorých špecifických regiónoch Slovenska. Je potrebné tiež zvážit' náhrady vysielatel'om, ktorí sú povinní ukončit' analógové vysielanie skôr ako im skončí platnost' príslušnej licencie a urýchlit' tak prechod na digitálne vysielanie.

\section{Záver}

V samotnom procese zavádzania DVB-T v SR možno očakávat' rôzne ekonomické dopady. Ide najmä o dopady na podnikatel'skú sféru a obyvatel'stvo (dotkne sa viac než milióna domácností). Ak sa štát nerozhodne pre dotovanie zariadení pre príjem DVB-T, proces digitalizácie vysielania nevyvolá $\mathrm{v}$ oblasti verejných financií drastické nároky na štátny rozpočet alebo iné verejné rozpočty, ani na nárast pracovných síl vo verejnej a štátnej správe.

\section{Literatúra}

[1] HRUDKAY, K. A KOL.: Sociálno-ekonomické a právne aspekty zavedenia pozemského digitálneho TV vysielania, VÚD, a.s., Žilina, December 2005

[2] http://www.rokovania.sk

[3] http://www.statistics.sk/

[4] http://europa.eu/

[5] http://www.rada-rtv.sk/

[6] http://www.teleoff.gov.sk 